\title{
Paleomagnetism of the Acatlan terrane, southern Mexico: evidence for terrane rotation
}

\author{
W. Fang ${ }^{1}$, R. Van der Voo ${ }^{1}$, R. Molina-Garza ${ }^{1}$, D. Moran-Zenteno ${ }^{2}$ \\ and J. Urrutia-Fucugauchi ${ }^{2}$ \\ ${ }^{\prime}$ Department of Geological Sciences, University of Michigan, Ann Arbor, MI 48109-1063 (U.S.A.) \\ ${ }^{2}$ Instituto de Geofisica, Universidad Nacional Autonoma de Mexico, Deleg. Coyoacan, 04510. Mexico D.F. (Mexico)
}

Received September 22, 1988; revised version received May 25, 1989

\begin{abstract}
232 drill samples were collected from 33 sites from the Acatlan Terrane, southern Mexico. The medium-grade metamorphosed basement rocks (schists, granitoid, greenstones) showed magnetic directions that are randomly distributed and no meaningful results could be obtained. However, late Paleozoic red beds. the Ordovician (?) Totoltepec Granite and the early Paleozoic (?) Tecomate Limestone (metamorphosed in Acadian times) give coherent paleomagnetic directions. The samples responded well to thermal demagnetization but not to alternating field demagnetization. The ages of the magnetizations are reasonably bracketed between Carboniferous and Jurassic. Compared with data from the North American craton and from the Oaxaca terrane, conclusive evidence for major north-south displacements of the Acatlan terrane is not present, but significant clockwise rotations of the terrane with respect to the craton and the adjacent Oaxaca terrane are quite evident. These rotations occurred during the Jurassic or Early Cretaceous.
\end{abstract}

\section{Introduction}

The paleogeographical position of the basement blocks of Mexico has been an enigma for years. In most paleoreconstruction models Mexico is displaced from where it is today; instead, its position was for a large part occupied by northwestern South America [1,2]. In order to avoid a superposition of Mexico and South America, numerous models have been suggested [2-6]. Few of these models, however, have derived firm support from geological or geophysical evidence. Moreover, it was recognized recently that southern Mexico is composed of a collage of allochthonous terranes with distinct stratigraphic and tectonic features. The paleopositions of these terranes remain almost entirely unconstrained.

The tectonic histories of these terranes are extremely important for the evolution of Mexico, and paleomagnetism is particularly suitable for determining past terrane motions. However, preCretaceous paleomagnetic results from Mexico are still sparse and sometimes controversial, owing to the extreme complexity of the area. We have embarked upon a systematic program of paleo- magnetic studies of Mexican rocks ([7,8], with this paper reporting new results from the Acatlan terrane, one of the largest Paleozoic or older basement terranes in southern Mexico.

\section{Geology and sampling}

The Acatlan terrane is located in the central part of southern Mexico (Fig. 1). It has a surface area of approximately $35,000 \mathrm{~km}^{2}$ but possibly larger. It is separated in places from neighboring terranes by high angle mylonitic zones, but the boundaries are often obscured by younger sediments or plutons of Late Mesozoic and Cenozoic ages. The northern boundary is covered by volcanic rocks of the Trans Mexican Volcanic Belt; further north of the belt some metamorphic rocks that might be correlated with basement rocks of the Acatlan terrane have been described from the Novillo and Peregrina canyons of the Sierra Madre Oriental, northeastern Mexico [9].

The basement rocks of the Acatlan terrane (the Acatlan Complex) consist of Lower Paleozoic volcanic and sedimentary sequences, metamorphosed in greenschist to eclogite facies. The 


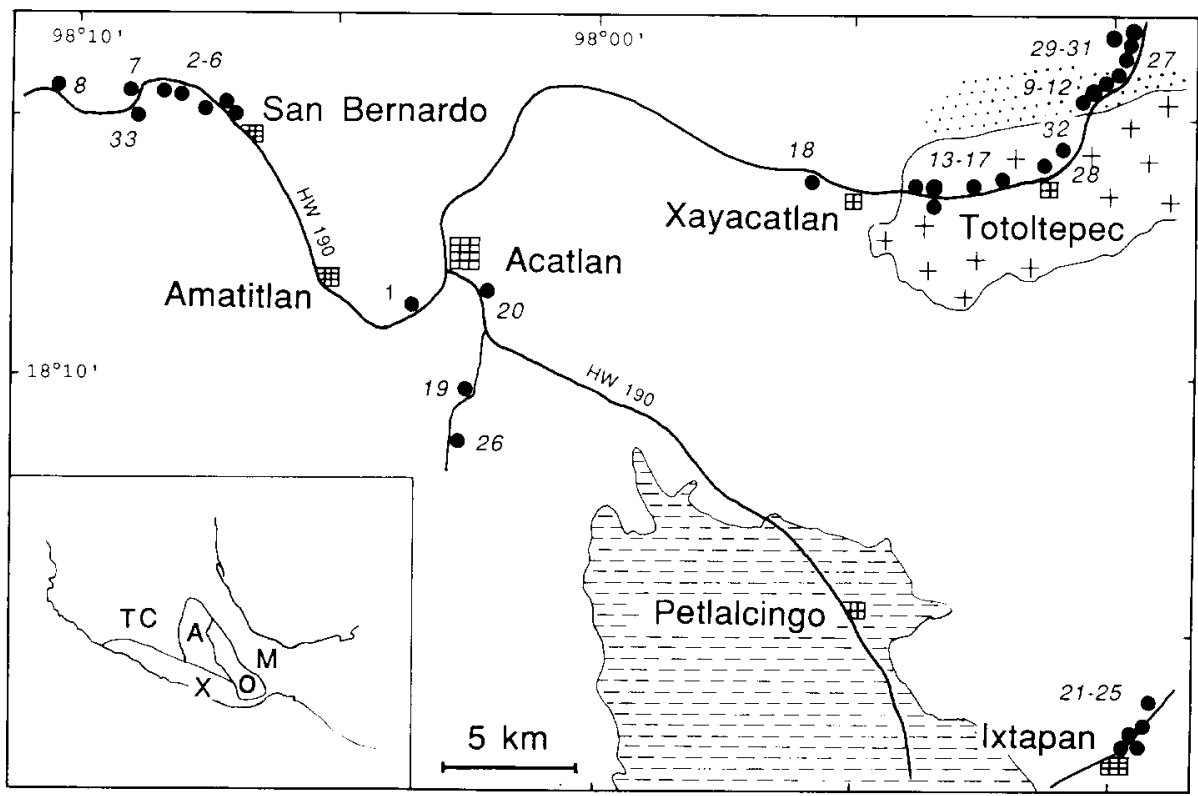

Fig. 1. Regional map of the Acatlan terrane. Sampling sites are indicated by black dots with numbers. Also indicated in the map are the "Matzitzi equivalent" red beds (stippled pattern) and Totoltepec Granite, both in the upper right corner, and the Mesozoic-Cenozoic sedimentary rocks around Petlalcingo. The inset map shows relative locations of terranes in southern Mexico: $A=$ Acatlan; $M=$ Maya $O=$ Oaxaca $T C=$ Tierra Caliente; $X=$ Xolapa.

Acatlan Complex has been divided into two lithostratigraphic subgroups $[10,11]$; the older one is composed of clastic metasediments, uncertain metavolcanics and a few mafic-ultramafic intrusions (Petlalcingo subgroup). The younger Acateco subgroup consists of meta-ophiolites, sometimes mylonitized granitoids and clastic sediments and limestones. A schematic stratigraphic column of the complex is presented in the lower part of Fig. 2. Radiometric studies [12] have identified Taconic $(\approx 440 \mathrm{Ma})$ and Acadian $(\approx 380 \mathrm{Ma})$ tectonometamorphic phases for the rocks. Ortega-Gutierrez $[10,11]$ recognized at least three regional preCarboniferous phases of deformation (Fig. 2), which imparted the foliated structure and characteristic isoclinal microfolding to the complex, as well as several less penetrative phases of subsequent deformation during the Late Paleozoic, Jurassic and Cretaceous-Tertiary times. OrtegaGutierrez [11] suggests that the evidence from the Acatlan Complex indicates a collisional midPaleozoic orogeny, associated with the closure of a Lower Paleozoic ocean possibly related to the Proto-Atlantic or Iapetus ocean. The suture is inferred to lie at the present contact between the Oaxaca and Acatlan complexes.
Also included in the Acatlan Complex is a cataclastic complex of undifferentiated granitoids with metasediment intercalations (Esperanza Granitoids), a trondhjemitic pluton (Totoltepec Granite) which has been deformed and slightly metamorphosed [10] and a swarm of undeformed dikes (San Miguel Dikes). A lead-alpha date of $440 \mathrm{Ma}$ for the pluton suggests an Ordovician age [13], whereas $\mathrm{Rb}-\mathrm{Sr}$ dates for the dikes suggest a Triassic age [12].

Volcanic and sedimentary rocks of Late Paleozoic and younger ages are folded but not metamorphosed. The fluvial sediments of the Matzitzi Formation of Pennsylvanian-Permian age [14] is the oldest unmetamorphosed formation in the area. The Mesozoic sequences contain several minor unconformities, testifying to at least three periods of uplift and denudation with moderate tectonic deformation [15,16].

A total of 232 samples, from 33 sites, were collected using a portable drill. The sampling localities are shown in Fig. 1. Schists of the Cosoltepec Formation (sites 1-3, 18), Xayacatlan greenstone and the Esperanza Granitoid (sites 4-8, 33) were mostly collected from the area west of Acatlan de Osorio, where the rock units outcrop 


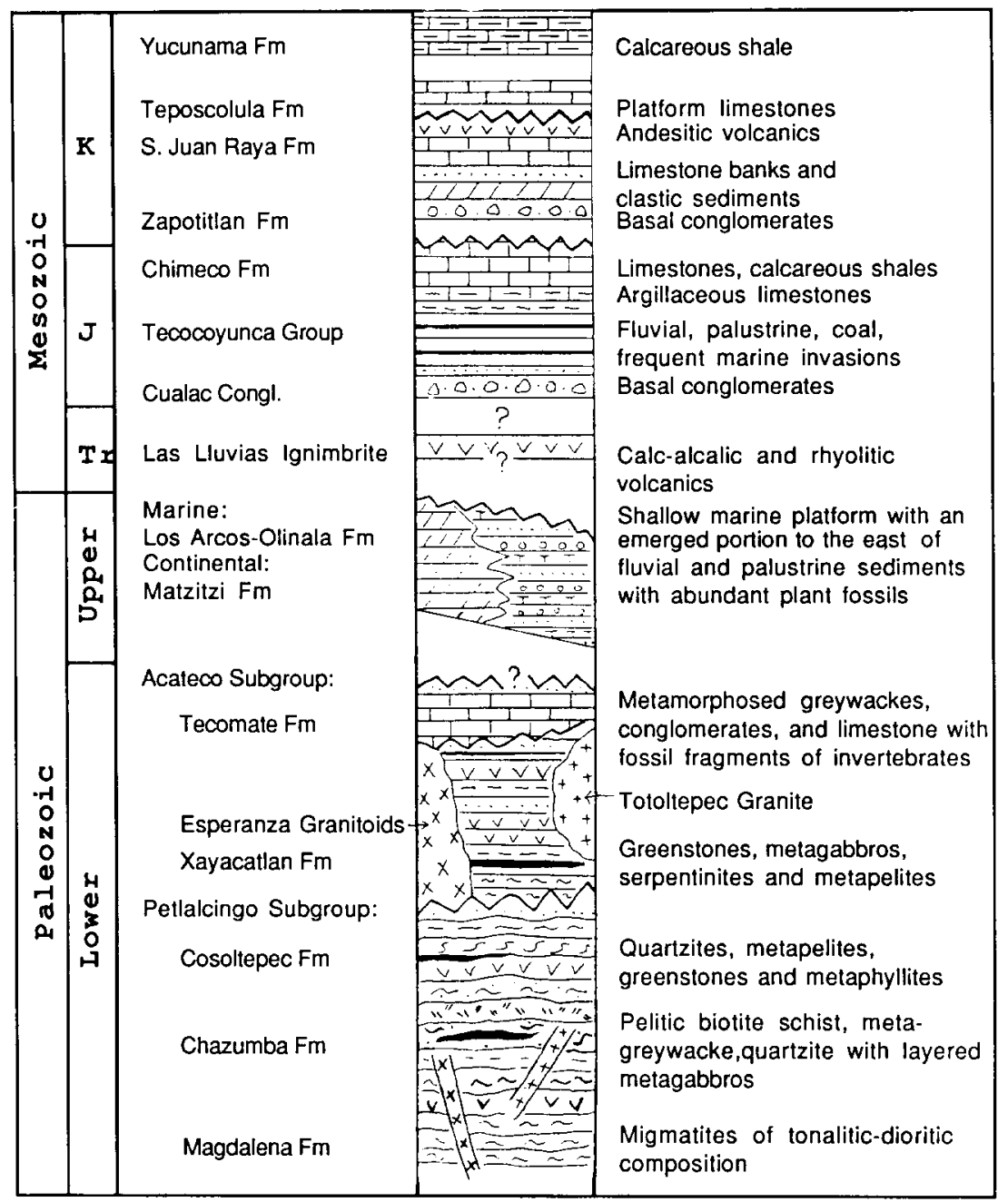

Fig. 2. Schematic stratigraphic column of the Acatlan terrane. Thickness of each unit is not to scale and only schematically shown.

in elongated zones running generally north to south; the foliation and lineation strikes are also north-south oriented. Samples were also obtained from the Totoltepec Granite (Sites 13-17, 28, 32), the Tecomate metamorphosed limestone (sites 19, 20, 26) and San Miguel dikes (sites 21-25).

"Matzitzi equivalent" [17] red beds (sites 9-12, 27) were collected along the road between Totoltepec and San Juan Icaquixtla, where they form a broad east-west-trending syncline which seems to be in tectonic contact with the Totoltepec intrusive. The age assignment of these unfossiliferous red beds as Pennsylvanian to Permian hinges critically on the lithostratigraphic correlation of Lopez-Ramos [17]. $30 \mathrm{~km}$ to the east of the sampled area, in its type section, the fossiliferous Matzitzi Formation unconformably overlies granulite gneisses of the Oaxaca Terrane and an undated cataclased intrusive. Jurassic yellowish sandstones overlying the "Matzitzi equivalent" red beds in apparent angular unconformity were also sampled (sites 29-31); The age of these sandstones provide an upper limit for the age of the red beds.

\section{Paleomagnetic results and analysis}

Samples were cut into $2.2 \mathrm{~cm}$ high specimens (2.5 $\mathrm{cm}$ diameter) and then measured in the paleomagnetic laboratory at the University of 
Michigan, using a two-axis ScT cryogenic magnetometer. Both alternating field (AF) and thermal demagnetizations were performed with Schonstedt equipment. Components of magnetization were identified by visual inspection of orthogonal vector diagrams [18], and their directions were determined by principal component analysis [19].

Natural remanent magnetizations (NRM) and demagnetization results from the schists (Cosoltepec Formation), greenstones and granitoid (Esperanza Formation), Triassic dikes (San Miguel Dikes) and Jurassic sediments are disappointing: the magnetic directions are generally randomly distributed and there is no consistency either within or between site(s). They are excluded from further analysis.

In contrast, specimens from the Totoltepec Granite, Tecomate Limestone and "Matzitzi equivalent" red beds all yield coherent paleomagnetic directions. Results from these rocks are presented below and summarized in Table 1.

AF demagnetization was generally not successful in isolating magnetizations carried by any of the Acatlan rocks, since the intensities of NRM hardly change after applying a peak field of 100 $\mathrm{mT}$. This indicates minerals of high coercivity spectra as the magnetization carriers. Thermal demagnetization was much more effective: heating
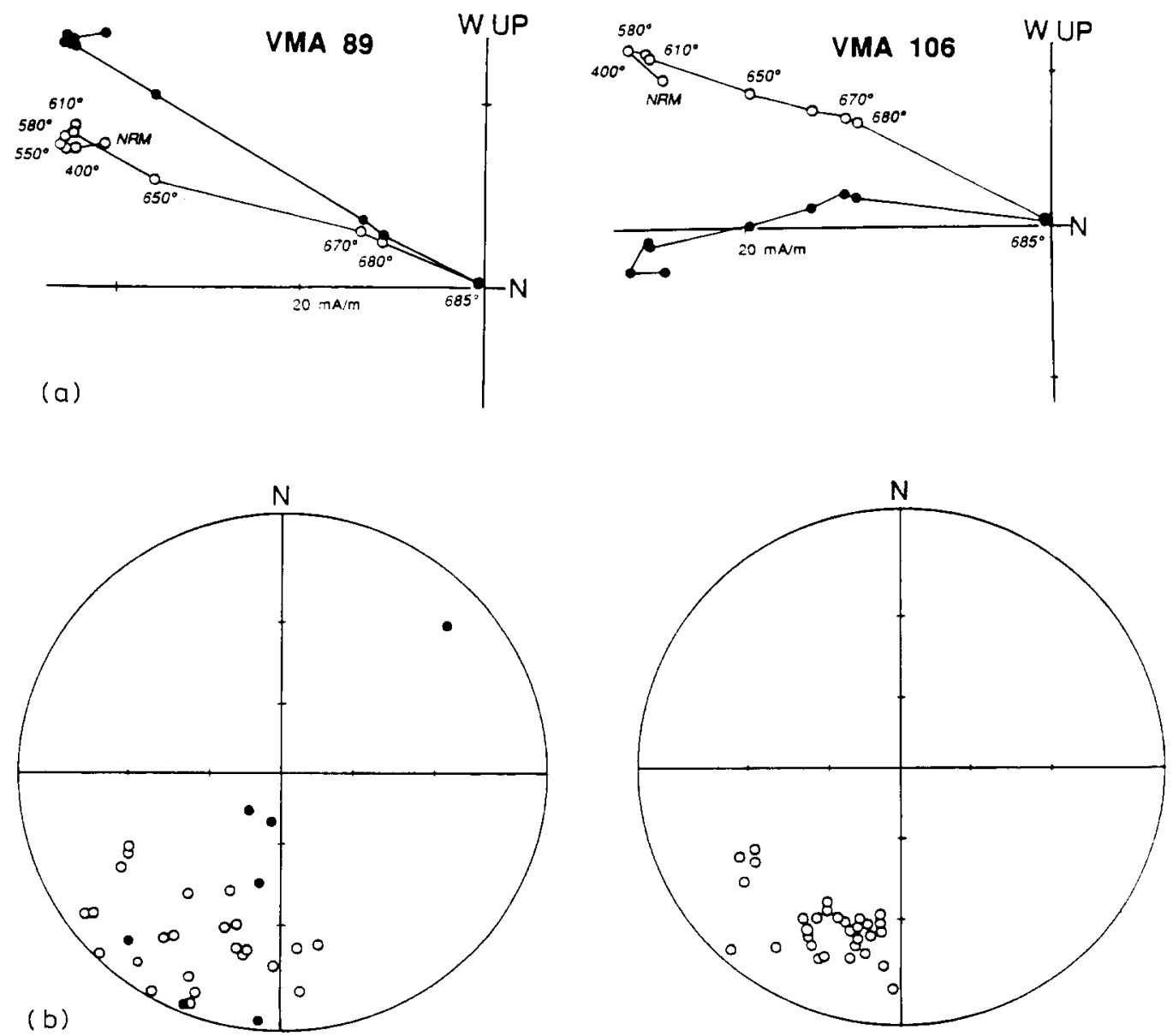

Fig. 3. (a) Orthogonal vector diagrams of two representative specimens from the Totoltepec Granite, showing the southwesterly and upward characteristic magnetization. Plotted points represent projections of the magnetic vector after each demagnetization step onto the horizontal (full symbols) and north-south vertical plane (open symbols). Intensities of magnetization are indicated along the axes, and temperatures $\left({ }^{\circ} \mathrm{C}\right.$ ) are given for each demagnetization step. (b) Equal-angle projections of the NRM's (left) and isolated characteristic magnetizations (right) of all samples (in-situ coordinates). Full (open) symbols represent projections onto the lower (upper hemisphere). 
TABLE 1

Summary of site-mean paleomagnetic data

\begin{tabular}{|c|c|c|c|c|c|}
\hline Site & $n / N$ & $k$ & $\begin{array}{l}\alpha_{95} \\
\left({ }^{\circ}\right)\end{array}$ & $\begin{array}{l}\text { In-situ } \\
D / I\left({ }^{\circ}\right)\end{array}$ & $\begin{array}{l}\text { Tilt corrected } \\
D / I\left(^{\circ}\right)\end{array}$ \\
\hline \multicolumn{6}{|c|}{ Totoltepec Granite } \\
\hline 13 & $4 / 4$ & 38.4 & 15.0 & $213.8 /-19.4$ & - \\
\hline 14 & $3 / 5$ & 604.3 & 5.0 & $239.7 /-22.7$ & - \\
\hline 15 & $6 / 6$ & 85.1 & 7.3 & $193.6 /-24.5$ & - \\
\hline 16 & $6 / 6$ & 268.9 & 4.1 & $191.2 /-24.9$ & - \\
\hline 17 & $4 / 6$ & 37.8 & 15.1 & $196.5 /-17.8$ & - \\
\hline 28 & $4 / 4$ & 21.2 & 20.4 & $211.7 /-18.8$ & - \\
\hline 32 & $4 / 5$ & 436.5 & 4.4 & $205.2 /-15.3$ & - \\
\hline \multicolumn{4}{|c|}{ Mean of all samples } & $\begin{array}{l}204.3 /-216 \\
k=24.1, \alpha_{95}=5.4^{\circ}\end{array}$ & \\
\hline Palec & & & & $65.5^{\circ} \mathrm{N}, 4.8^{\circ} \mathrm{E}$ & \\
\hline \multicolumn{6}{|c|}{ Tecomate Limestone } \\
\hline 19 & $11 / 13$ & 40.0 & 7.3 & $9.3 /-36.4$ & $336.4 / 3.0$ \\
\hline 20 & $8 / 8$ & 36.5 & 9.3 & $353.3 /-45.0$ & $317.8 /-8.8$ \\
\hline 26 & $6 / 7$ & 14.8 & 18.0 & $330.4 /-29.9$ & $300.9 /-6.5^{a}$ \\
\hline \multicolumn{4}{|c|}{ Mean of all samples } & $\begin{array}{l}354.8 /-38.7 \\
k=16.4, \alpha_{95}=7.4^{\circ}\end{array}$ & $\begin{array}{l}(323.5 /-3.0) \\
\left(k=11.8, \alpha_{95}=8.8^{\circ}\right)\end{array}$ \\
\hline Palec & & & & $49.8^{\circ} \mathrm{N}, 89.5^{\circ} \mathrm{E}$ & $\left(49.1^{\circ} \mathrm{N}, 147.4^{\circ} \mathrm{E}\right)$ \\
\hline \multicolumn{6}{|c|}{ Matzitzi red beds } \\
\hline 9 & $6 / 7$ & 46.9 & 9.9 & $212.3 / 35.5$ & $231.2 / 27.2$ \\
\hline 10 & $7 / 7$ & 92.1 & 6.3 & $11.1 /-34.2$ & $39.2 /-58.6$ \\
\hline 11 & $9 / 9$ & 77.3 & 5.9 & $31.5 /-19.5$ & $76.7 /-65.9$ \\
\hline 12 & $6 / 7$ & 79.4 & 7.6 & $10.5 /-12.9$ & $115.4 /-81.9$ \\
\hline 27 & $4 / 4$ & 96.2 & 9.4 & $351.2 /-9.8$ & $18.1 /-52.0$ \\
\hline \multicolumn{4}{|c|}{ Mean of all samples } & $\begin{array}{l}17.9 /-23.9 \\
k=18.6, \alpha_{95}=6.1^{\circ}\end{array}$ & $\begin{array}{l}24.3 /-40.9^{b} \\
k=25.1, \alpha_{95}=5.2^{\circ}\end{array}$ \\
\hline Palec & & & & $54.8^{\circ} \mathrm{N}, 50.7^{\circ} \mathrm{E}$ & $42.4^{\circ} \mathrm{N}, 51.6^{\circ} \mathrm{E}$ \\
\hline
\end{tabular}

Explanation: $n / N$ is the ratio of samples used in the statistical analysis to the number of samples demagnetized; $k$ and $\alpha_{95}$ are the statistical parameters associated with the means.

${ }^{a}$ Each sample from this site has different bedding correction, the corrected mean has a $k=5.3, \alpha_{95}=32^{\circ}$, indicating a negative fold test.

${ }^{b}$ The mean after $40 \%$ unfolding.

to $370^{\circ} \mathrm{C}$ or higher reduced the intensities to near-zero. Hence most specimens were treated thermally.

\subsection{Totoltepec Granite}

These slightly metamorphosed granites (lower greenschist facies) carry fairly strong, simple and directionally very stable magnetizations. Fig. 3 shows two representative demagnetization diagrams. The NRM's remain stable in fields up to $100 \mathrm{mT}$ during AF treatment, whereas a generally univectorial characteristic magnetization is readily revealed during thermal treatment. This magnetization points south to southwest with an upward inclination (Fig. 3) based on a discrete blocking temperature interval generally between $550^{\circ}$ and $680^{\circ} \mathrm{C}$. Such high coercivity and blocking temperatures are strongly indicative of hematite as the magnetic carrier.

The age of the characteristic magnetization is probably secondary, not only because of the metamorphism that might have changed the primary remanence, but also because the granite has been heavily sericitized. In thin sections abundant alteration products like chlorite and sericite can be seen, and large specularite grains associated with the chlorite minerals are abundant. In the outcrops, hematite has been recognized as veinlets of 
136
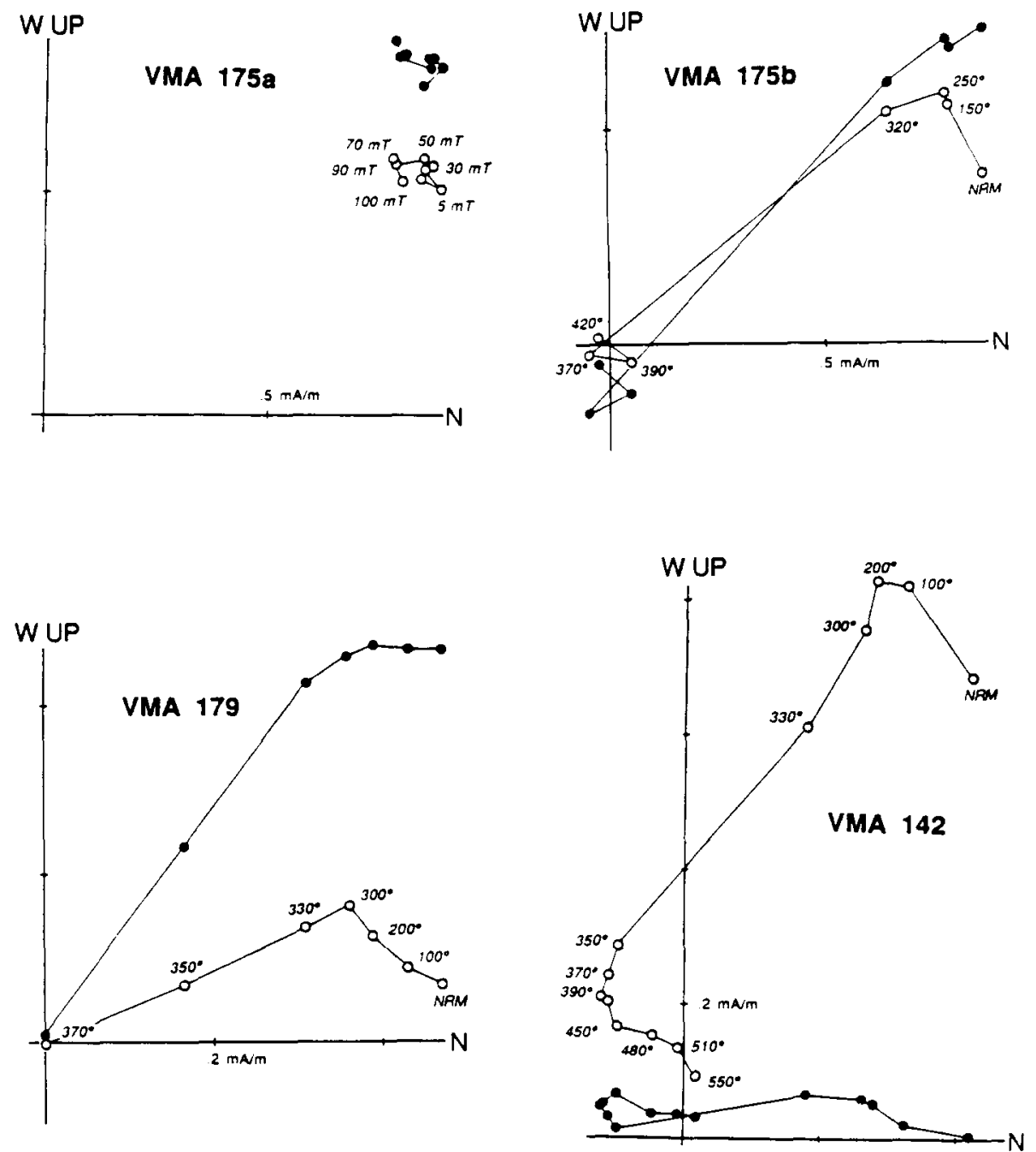

Fig. 4. Orthogonal vector diagrams (as in Fig. 3) of representative specimens from the Tecomate Limestone. Specimens VMA 175a and VMA 175b were cut from the same core. VMA 175a was demagnetized by AF technique, with the NRM remaining unaffected in fields up to $100 \mathrm{mT}$, while VMA $175 \mathrm{~b}$ revealed a northwest upward characteristic magnetization during thermal demagnetization. VMA 142 carried not only the characteristic component but also a southwesterly upward component which is similar to the characteristic direction of the Totoltepec Granite.
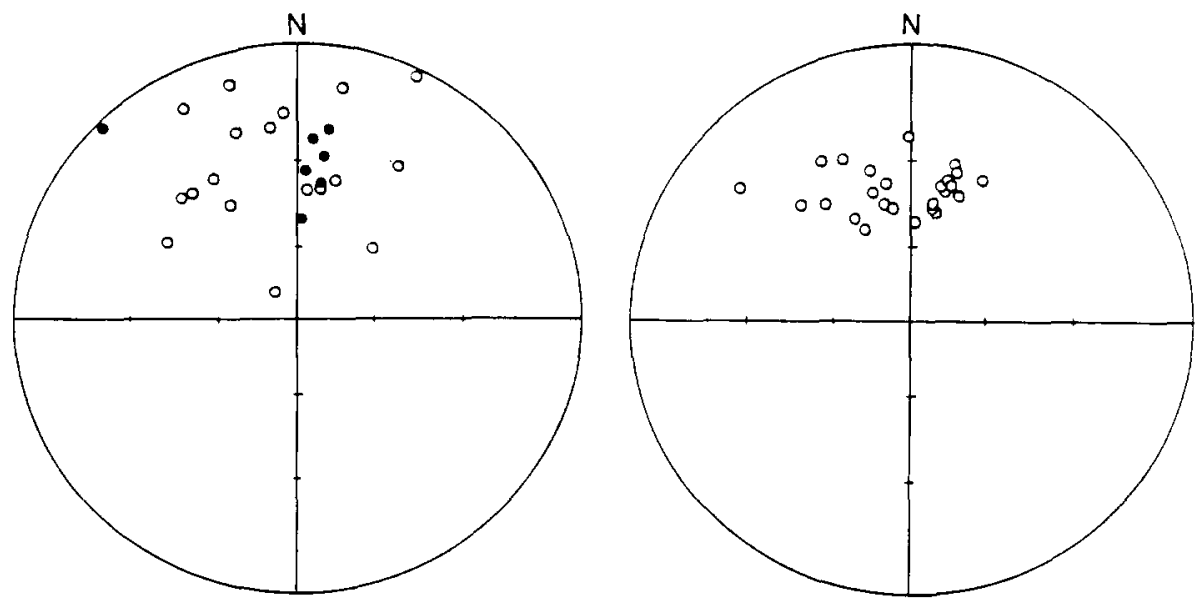

Fig. 5. Equal-angle projections (as in Fig. 3) of the NRM'S (left) and isolated characteristic northerly magnetizations (right) of all samples from the Tecomate Limestone. All directions are in in-situ coordinates. 
VMA 69

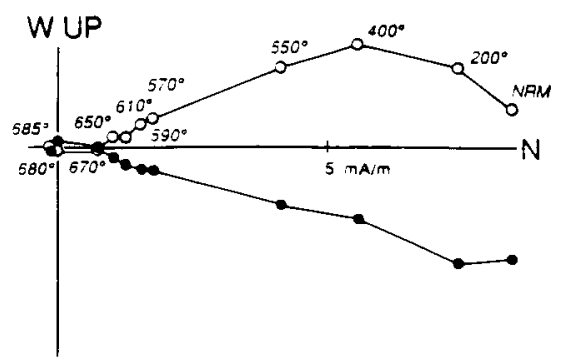

VMA 71

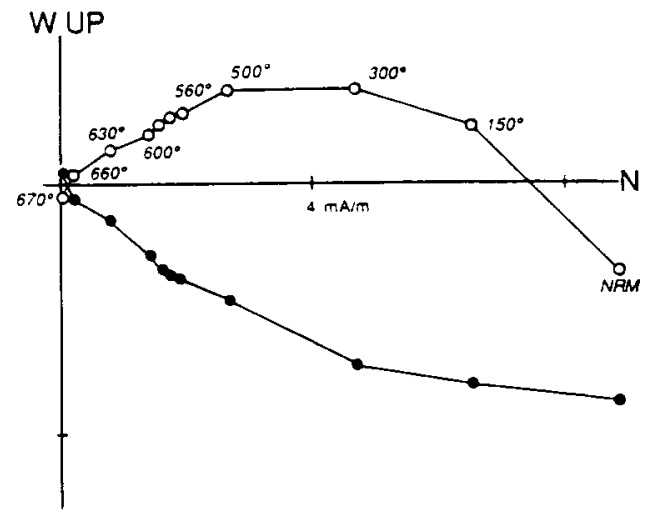

VMA 78a
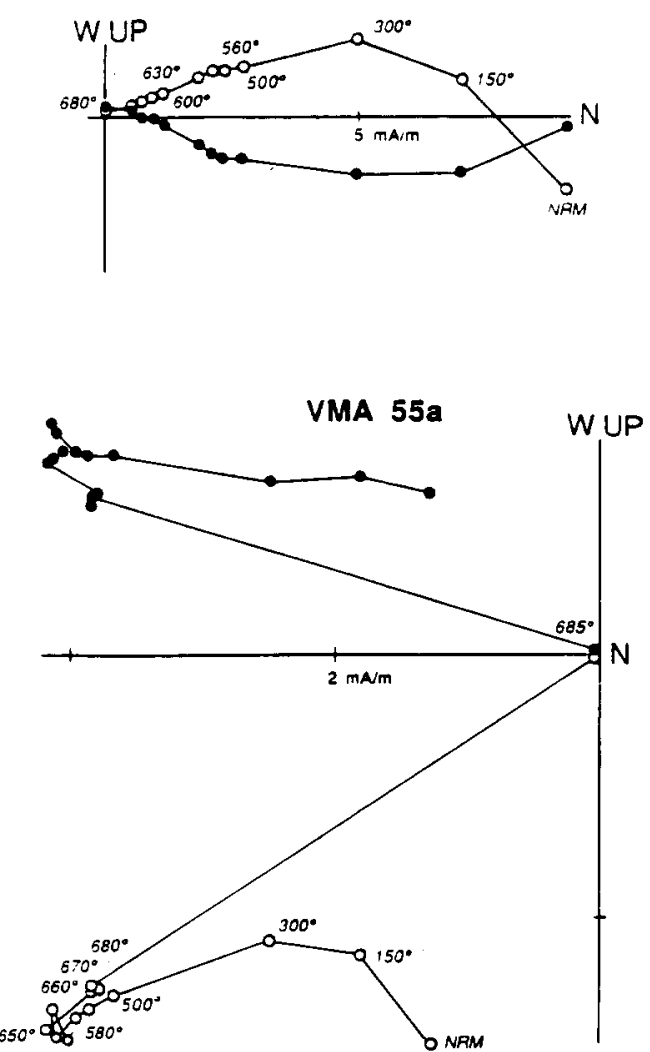

Fig. 6. Orthogonal vector diagrams (as in Fig. 3) of four representative specimens from the "Matzitzi equivalent" red beds. In VMA 55 a the characteristic component occurs with both normal and reversed polarities.

clearly secondary nature. Thus the granite may have acquired its magnetization long after intrusion.

\subsection{Tecomate Limestone}

These cleavaged limestones displayed in many cases only one magnetization during thermal demagnetization (Fig. 4), with a north to northwest declination and intermediate inclination (Fig. 5). The magnetization is very resistant to AF treatment but relatively "soft" to thermal treatment, as shown for two specimens (VMA 175A and VMA $175 \mathrm{~B}$ ) cut from the same core. Heating to $370^{\circ} \mathrm{C}$ reduces the NRM's to nearly zero, with the principal blocking temperatures between $320^{\circ}$ and $370^{\circ} \mathrm{C}$.

In most specimens the north to northwest characteristic components were totally eliminated at $370^{\circ} \mathrm{C}$. However, in a few specimens (e.g. VMA
142 in Fig. 4) a higher-temperature component remains after removal of the characteristic component. This component was revealed between $420^{\circ}$ and $520^{\circ}$, and it has a south-southwesterly direction similar to that found in the Totoltepec Granite.

Acquisition of isothermal remanent magnetization (IRM) by two independent samples shows that saturation in fields up to $1.4 \mathrm{~T}$ is not yet achieved. Because AF treatment up to $100 \mathrm{mT}$ does not break down the NRM's, magnetite can be excluded as the major magnetic carrier. Goethite and pyrrhotite are also unlikely magnetization carriers, because of their low Curie temperatures (about $120^{\circ} \mathrm{C}$ and $320^{\circ} \mathrm{C}$, respectively) that are well below the observed blocking temperatures $\left(320^{\circ}\right.$ to $\left.370^{\circ} \mathrm{C}\right)$ in the limestones. Reflected-light optical microscopy reveals very few opaque mineral grains, while scanning electron 
microscopy (SEM) with energy-dispersive analysis shows submicron grains of iron oxide (hematite) as the only possible magnetic minerals in the limestone. Thus the mineral phase responsible for the magnetization is most likely extremely finegrained hematite. Although the Curie point of hematite is relatively high $\left(\approx 680^{\circ} \mathrm{C}\right)$, submicron-sized crystals can have much lower blocking temperature spectra.

At site 26 the strata are intensely folded. We collected 7 samples from different bedding orientations to conduct a fold test. The characteristic component of each specimen shows in-situ directions similar to that seen in other sites. After performing a simple fold test [20], however, the directions display a larger dispersion; the precision parameter $k$ decreases from $14.8\left(k_{1}\right)$ to 5.3 $\left(k_{2}\right)$, suggesting a negative fold test. The age of the characteristic magnetization therefore must be younger than the folding.

\section{3. "Matzitzi-equivalent" red beds}

Where sampled, these fine-grained red sandstones are unmetamorphosed. Specimens from site 27 are yellowish in color. Samples from this site as well as the purple colored samples from sites 9-12 contain stable remanences. Representative thermal demagnetization diagrams are shown in Fig. 6. At least two magnetic components could be isolated. The first one, pointing northerly and downward conforms to the present day geomagnetic field direction and is easily removed below $300^{\circ} \mathrm{C}$, suggesting that it is most likely of recent origin. The second component, revealed above 300 $500^{\circ} \mathrm{C}$, generally also has a north to northeast declination but with an upward inclination. This direction can be seen in a majority of the specimens and we call it the characteristic direction of these red beds.

In some specimens (VMA 69 and 78 in Fig. 6) the characteristic component does not decay exactly towards the origin but appears to bypass it, indicating that there is a small component with an extremely high blocking temperature $\left(>670^{\circ} \mathrm{C}\right)$ left unresolved; the accurate direction of this component could not be determined because of slightly noisy behavior at temperatures above $670^{\circ} \mathrm{C}$.

At site 9 the specimens revealed both normal and reversed directions for the characteristic component, as shown by VMA 55A in Fig. 6. After removing a northerly and down component by $300^{\circ} \mathrm{C}$, which we interpret as the effect of overprinting by the recent field, a northerly and upward component could be isolated from $300^{\circ}$ to $600^{\circ} \mathrm{C}$, which is identical to the characteristic component seen in all other sites of the red beds. However, above $600^{\circ} \mathrm{C}$ a southwesterly component with a downward inclination dominates. This component has a very high and discrete blocking temperature interval, between $660^{\circ}$ and $680^{\circ} \mathrm{C}$, and is roughly antipodal to the characteristic component. The co-existence of both normal and reversed polarity directions in the same specimen implies that the rock acquired its magnetizations over a period long enough for the Earth's field to reverse itself.

After rotating the beds back to the horizontal according to their bedding orientation, the clustering of characteristic directions decreases with the most notable effect being that the dual polarity directions are no longer antipodal (Fig. 7). This indicates that the characteristic component is not likely to be primary. However, the vector directions of the sites bypass one another during unfolding; if we perform stepwise unfolding we observe an improvement of the precision parameter at $40 \%$ unfolding (Fig. 7). The improvement is not statistically significant, though it suggests that the characteristic component was probably acquired contemporaneous with the deformation.

\section{Discussion}

The Totoltepec Granite, Tecomate Limestone and "Matzitzi equivalent" red beds' all yield well defined characteristic magnetizations (Table 1), which in all three cases appear to be ancient but secondary. In all tree rock units, the magnetizations are carried by hematite. As we will discuss below, these characteristic directions do not conform to any expected directions from the apparent polar wander path (APWP) for North America. That this is an indication of displacement of the Acatlan terrane relative to North America is very likely but quantification of the displacement critically depends upon the ages of the magnetizations and resolution of structural attitudes. Although it is not possible to assign precise ages to the magnetization, we can nevertheless constrain these ages to the Late Paleozoic to the Late Jurassic interval 


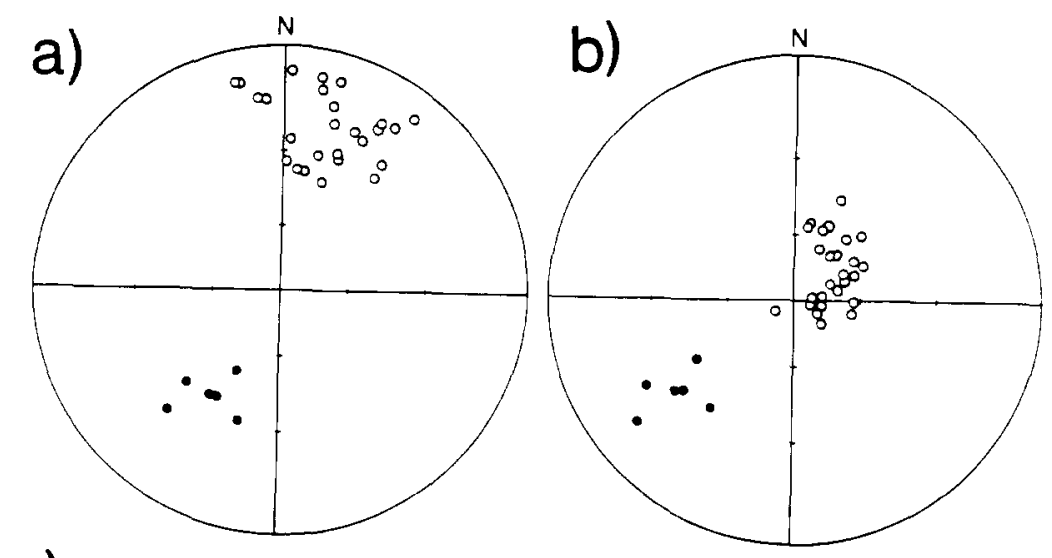

C)

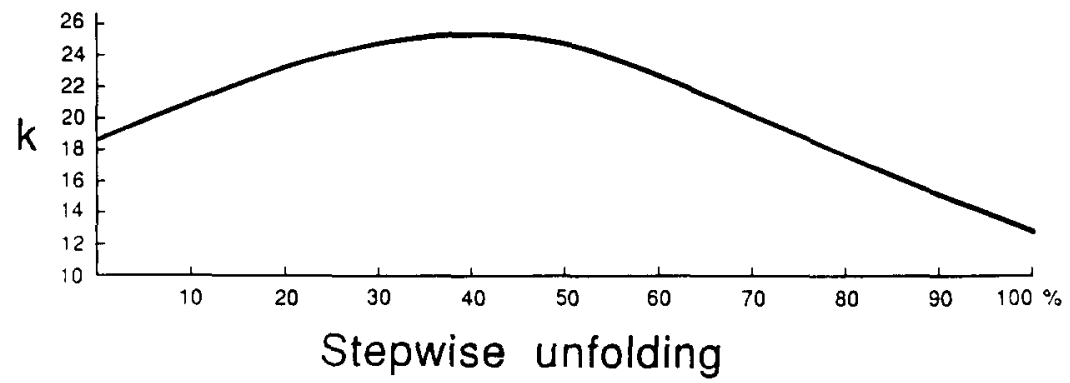

Fig. 7. Top: Characteristic magnetizations of all samples from the Matzitzi red beds: (a) in-situ coordinates; (b) after full tilt correction. Bottom: (c) Results of stepwise unfolding, showing the precision parameter $k$ changing from 18.6 (in-situ) to 25.1 (40\% unfolding) and then to 12.7 (100\% unfolding). This suggests that the magnetization was acquired contemporaneous with or after the folding.

because of the generally known Acadian ages of metamorphism [12] and the known post-Jurassic paleomagnetic directions for Acatlan [21,22].

Samples from the Totoltepec Granite all have a unique and reversed polarity defined by very similar magnetic behavior in all specimens, indicating that the rocks were evenly magnetized in a relatively short period. The characteristic magnetization, however, does not appear to be primary, considering it is carried by hematite and given the alteration of the rocks. We argue that the magnetization is carried by hematite grains which grew after the complex was uplifted and cooled from metamorphic conditions in post-Acadian time. Characteristic directions from each site are well grouped around the mean (Table 1), thus rendering the possibility of significant deformation since the acquisition of the magnetizations unlikely.

The characteristic magnetizations carried by the Tecomate Limestone are clearly post-folding, as mentioned earlier. According to Ortega-Gutierrez
[11], the last major tectonometamorphic event (Acadian) ended before Carboniferous time. We suggest that the remanence was acquired upon cooling and uplift after the Acadian orogeny; the intermediate blocking temperatures of the characteristic magnetization $\left(320-370^{\circ} \mathrm{C}\right)$ indicate it must postdate the intermediate-grade metamorphism of the Acatlan Complex. The high-temperature component, also carried by hematite, has the same direction as that observed in the Totoltepec Granite; it may be older or younger than the characteristic northerly and upward magnetization.

From stepwise-unfolding analysis, the magnetizations carried by the "Matzitzi equivalent" red beds seem to have a syn-folding to post-folding age. The time of folding itself has not been well constrained, but must have occurred before Jurassic time since Jurassic sediments in the area show insignificant folding. The contact between the "Matzitzi equivalent" red beds and meta- 
morphosed lower Paleozoic Acatlan Complex (including the Totoltepec Granite) is likely to be tectonic, so the tectonostratigraphic relationship between the two is not known and they may have had quite different tectonic histories.

Thus, the older age limits of the observed magnetizations appear to be the (Devonian) time for the Acadian orogeny for the Totoltepec granite and the Tecomate Limestone and Carboniferous time (as the oldest possible age of deposition) for the "Matzitzi equivalent" red beds; the failing of the fold test for these red beds is likely to restrict their age of magnetization to Permian or younger times.

The younger age limit of the three characteristic remanences can be bracketed to preCretaceous, because Early to Middle Cretaceous rocks from southern and western Acatlan [21,22] have shown paleomagnetic directions that match those expected from the apparent polar wander path (APWP) for the North America craton, implying that by that time the Acatlan Terrane was already a part of North America. Therefore, any magnetization acquired after the Early Cretaceous should conform to those expected from the APWP for the craton. Our data do not show such a match and we believe that they must be older than Early Cretaceous.

The ages of our three magnetization directions, then, are bracketed between the Carboniferous and the Jurassic. However, the three formation means are different from each other, suggesting that the magnetizations were acquired at different times within this interval. Before addressing the most plausible ages of magnetization as deduced from a comparison between our results and those from the North American craton, it is important to discuss possible concerns about the structural attitudes of the rocks. More specifically, we wish to address the question whether any significant tilt may have occurred after the secondary magnetizations were acquired, and if so, what effect this may have on the directions of magnetization.

As noted already, the results from the red beds and the limestones fail the fold test, indicating that the magnetizations were acquired after (or possibly, for the red beds, during) the folding. Overlying the red beds are nearly flatlying Jurassic sandstones, indicating that the red beds have not been tilted significantly after the Jurassic. We argue, moreover, that the red beds are unlikely to have been severely tilted after the folding, since site 9 with the shallowest dip is nearly conformable to the overlying Jurassic beds (see also [17, fig. 10-3]). Thus a worst case scenario involves only moderate tilts. For the limestones and the granite no such constraints exist.

The present-day strikes of limestone outcrops are north-south, whereas those for the red beds and probably also for the adjacent Totoltepec Granite are east-west. The effects of tilt about east-west strikes on the directions of the red beds and the granite will be primarily seen in the inclination, whereas at least for moderate tilts, the declinations will remain NNE-SSW. Hence, the uncertainties associated with hypothetical structural tilts of these units are primarily with the inclinations and not the declination. Our conclusions, which are based foremost on the declinations, are therefore not impacted severely by the uncertainty about possible postfolding tilts of the red beds and granite. For the limestones with their north-south striking outcrops, a post-folding and,

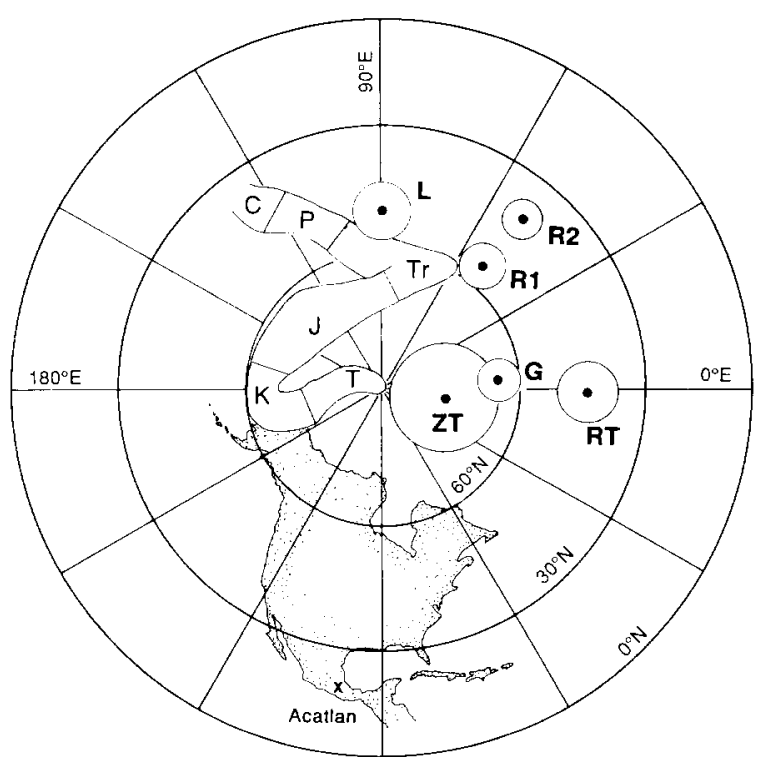

Fig. 8. Pole positions calculated from the characteristic magnetizations from the Acatlan rocks, compared with the apparent polar wander path for stable North America by Irving [23] with modifications for Late Triassic-Jurassic times by Van der Voo [24]. $L=$ Tecomate Limestone; $R I$ (in-situ) and $R 2$ (40\% unfolding) = "Matzitzi equivalent" red beds; $G=$ Totoltepec Granite; $Z T=$ Zorillo Formation and $R T=$ Rosario Formation [21]. Location of Acatlan is indicated by a cross. 

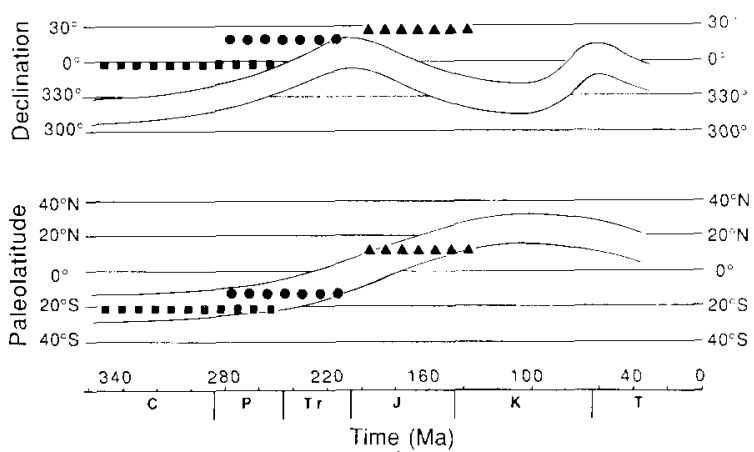

Fig. 9. Observed versus expected paleolatitudes and paleomagnetic declinations for the Acatlan terrane. Squares = Tecomate Limestone; dots = "Matzitzi equivalent" red beds; triangles $=$ Totoltepec Granite. Data for North America are from Van der Voo [24].

hence, post-metamorphic tilt could impact both declination and inclination.

The paleomagnetic poles from this study can be compared with those from the North American craton in Fig. 8; also plotted are two Early to Middle Jurassic poles [21] from the Tecocoyunca Group from Acatlan (ZT, $75.3^{\circ} \mathrm{N}, 351.0^{\circ} \mathrm{E}, k=$ 16.0, $\alpha_{95}=11.8^{\circ}$, from the Zorillo Formation; $\mathrm{RT}, 43.7^{\circ} \mathrm{N}, 358.1^{\circ} \mathrm{E}, k=14.0, \alpha_{95}=7.8^{\circ}$, from the Rosario Formation). The Acatlan poles fall close to the APWP but all are offset to the right. However, if we assume that the Acatlan terrane has rotated in a clockwise sense by about $30^{\circ}$, then our three poles can be restored to fall directly on the reference APWP, with pole L (Tecomate Limestone) in the Carboniferous segment, pole R1 ("Matzitzi equivalent" red beds) in the Permo-Triassic segment and pole $\mathrm{G}$ (Totoltepec Granite) in the Jurassic segment. Whether this "inferred" agreement indicates the true ages of the characteristic components cannot be determined at present, but at any rate it strongly implies that Acatlan has experienced a clockwise rotation relative to the craton. Böhnel [21] reached a similar conclusion. It is noticeable that our pole $G$ from the Totoltepec Granite falls in between Böhnel's two Early to Middle Jurassic poles obtained from sediments in the southeastern part of the Acatlan terrane (poles ZT and RT in Fig. 8). Pole G seems, therefore, likely of Jurassic age.

In Fig. 9 the observed paleolatitudes and paleomagnetic declinations for Acatlan are plotted according to the results of this study with tentative age brackets as discussed above. Also plotted are the expected paleolatitudes and paleomagnetic declinations calculated from the recent paleopole list for North America [24], supposing that Acatlan has been always in its present position relative to the craton. It can be seen that the three observed paleolatitudes $\left(11^{\circ} \mathrm{N}\right.$ for the Totoltepec Granite; $13^{\circ} \mathrm{S}$ for the "Matzitzi equivalent" red beds; $22^{\circ} \mathrm{S}$ for the Tecomate limestone), conform well to the Jurassic, Permo-Triassic and Carboniferous segments respectively, as suggested by the earlier interpretation from Fig. 8, whereas the observed declinations show consistent eastward deviations from those expected for the corresponding segments. Recalling that the structural uncertainties for the red beds and the granite would primarily affect the inclinations and not the declinations, we argue that this suggests that a relative clockwise rotation of about $30^{\circ}$ has occurred during the time after the rocks acquired their characteristic magnetizations (Early Jurassic or later given Böhnel's ZT and RT poles) but before the Early Cretaceous.

The Oaxaca terrane, just to the east of the Acatlan terrane (Fig. 1), has yielded two paleomagnetic results for the same interval of late Paleozoic-Late Jurassic as inferred for our study $[7,8]$. The paleomagnetic directions agree in inclination and, hence, paleolatitude, with those extrapolated from the North American craton, as do the results from our present study. On the

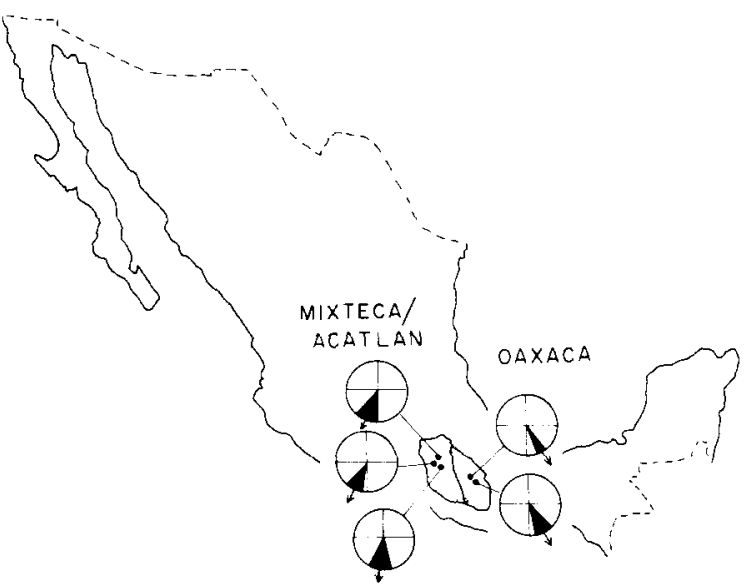

Fig. 10. Paleomagntic directions (arrows) with their associated confidence limits (black) for the Acatlan terrane (this study) and the Oaxaca terrane [7,8], illustrating the inferred relative rotation between the two. 
other hand, the Oaxaca declinations (average $154^{\circ}$ ) deviate, if anything, in a counterclockwise sense, whereas the declinations from our present study deviate in a clockwise sense for pre-Cretaceous time (Fig. 10). It seems clear, therefore, that relative rotations occurred between the Acatlan and Oaxaca terranes during the Mesozoic and that final juxtaposition of the terranes was Jurassic to Early Cretaceous in age, much younger than previously suggested [11]. Considering that most paleoreconstruction models require that southern Mexico reached its present position after the breakup of Pangea by means of post-Triassic tectonic processes, results from this study provide some constraints about the nature of the tectonic evolution of southern Mexico.

\section{Acknowledgements}

We thank R.J. Johnson for helpful discussions and Dongwoo Suk for his help with SEM work. This study was supported by the Division of Earth Sciences, the National Science Foundation, grant EAR 83-13085.

\section{References}

1 E.C. Bullard, J.E, Everett and A.G. Smith, A symposium on continental drift, IV. The fit of the continents around Atlantic, Philos. Trans. R. Soc. London 258, 41-51, 1965.

2 R.H. Pilger, A closed Gulf of Mexico; pre-Atlantic ocean plate reconstruction and the early rift history of the Gulf of Mexico and North Atlantic, Gulf Coast Assoc. Geol. Soc. Trans. 28, 385-393, 1978.

3 G.L. Freeland and R.S. Dietz, Plate tectonic evolution of Caribbean-Gulf of Mexico region, Nature 232, 20-23, 1971.

4 J.L. Walper and C.L. Rowett, Plate tectonics and the origin of the Caribbean sea and the Gulf of Mexico, Gulf Coast Assoc. Geol. Soc. Trans. 22, 105-116, 1972.

5 L.T. Silver and T.H. Anderson, Possible left-lateral middle Mesozoic disruption of the southwestern North American craton margin, Geol. Soc. Am. Abstr. Progr. 6, 955, 1974.

$6 \mathrm{~J}$. Urrutia-Fucugauchi, On the tectonic evolution of Mexico: paleomagnetic constraints, in: Van der Voo, R., et al., eds., Plate Reconstruction from Paleozoic Paleomagnetism, R. Van der Voo et al., eds., Am. Geophys. Union, Geodyn. Ser. 12, 29-47, 1984.

7 M.M. Ballard, R. Van der Voo and J. Urrutia-Fucugauchi, Paleomagnetic results from Grenville-aged rocks from Oaxaca, Mexico: evidence for a displaced terrane, Precambrian Res. (in press).

8 C. McCabe, R. Van der Voo and J. Urrutia-Fucugauchi,
Late Paleozoic or early Mesozoic magnetizations in remagnetized Paleozoic rocks, State of Oaxaca, Mexico, Earth Planet. Sci. Lett. 91, 205-213, 1988.

9 F. Ortega-Gutierrez, El Gneis Novillo y rocas metamorficas asociadas en los canones del Novillo y de La Peregrina, area de Ciudad Victoria, Tamaulipas, Univ. Nal. Auton. Mexico, Rev. Inst. Geol. 2, 19-30, 1978.

10 F. Ortega-Gutierrez, Estratigrafia del Complejo Acatlan en la Mixteca Baja, Estados de Puebla y Oaxaca, Univ. Nal. Auton. Mexico, Rev. Inst. Geol. 2, 112-131, 1978.

11 F. Ortega-Gutierrez, Metamorphic belts of Southern Mexico and their tectonic significance, Geof. Int. 20-3, 177-202, 1981.

12 M. Ruiz-Castellanos, Rubidium-Strontium geochronology of the Oaxaca and Acatlan metamorphic areas of southern Mexico, 178 pp., Ph.D. Thesis, University of Texas at Dallas, Texas, 1979.

13 C. Fries, Jr., C. Rincon-Orta, J. Solorio-Munguia, E. Schmitter-Villada and $Z$. de Cserna, Una edad radiometrica Ordovicica de Totoltepec, Estado de Puebla. Sociedad Geologica Mexicana, Libro Guia de la Excursion MexicoOaxaca, pp. 164-166, 1970.

14 A. Silva-Pineda, Plantas del Pennsylvanico de la region de Tehuacan, Inst. Geol., UNAM, Pue. Paleontol. Mex. 29. 1970.

15 G.P. Salas, Bosquejo geologico de la cuenca sedimentaria de Oaxaca, Bol. Asoc. Mex. Geol. Pet. 1, 51-66, 1949.

16 I. Ferrusquia, Geologia del area Tamazulapan-TeposcolulaYanhuitlan, Mixteca Alta, Estado de Oaxaca, Sociedad Geologica Mexicana, Libro Guia de la Excursion MexicoOaxaca, pp. 97-119, 1970

17 E. Lopez-Ramos, Geologica de Mexico, 2nd ed.. 3 vols., Edicion Escolar, Mexico D.F., 1979.

18 J.D.A. Zijderveld, AC demagnetization of rocks: analysis of results, in: Methods in Paleomagnetism. D.W. Collinson, K.M. Creer and S.K. Runcorn, eds., pp. 254-286. Elsevier, Amsterdam, 1967.

19 J.L. Kirschvink, The least-squares line and plane and the analysis of paleomagnetic data, Geophys. J.R. Astron. Soc. $62,699-718,1980$.

20 M.W. McElhinny, Statistical significance of the fold test in paleomagnetism. Geophys. J. R. Astron. Soc. 8, 338-340. 1964.

$21 \mathrm{H}$. Böhnel, Paleomagnetic results from the Tecocoyunca Group (State of Oaxaca) and the Tecomazuchil and Morelos formations (Puebla), Union Geofis. Mex., A.C., Mem. Reun. Anu. 1985, pp. 276-281, 1985.

22 J. Urrutia-Fucugauchi, Paleomagnetic study of the Cretaceous Morelos Formation, Guerrero State, southern Mexico, Tectonophysics 147, 121-126, 1988.

23 E. Irving, Paleopoles and paleolatitudes of North America and speculations about displaced terranes, Can. J. Earth Sci. 16, 669-694, 1979.

24 R. Van der Voo, Paleomagnetism of continental North America: the craton, its margins, and the Appalachian belt, in: Geophysical Framework of the Continents, L.C. Pakiser and W.D. Mooney, eds., Geol. Soc. Am. Mem. 172. in press, 1989. 